\title{
INFLUENCE OF FUSARIC ACID ON URINARY EXCRETION OF CATECHOLAMINES; A CLINICAL STUDY WITH PARTICULAR EMPHASIS ON THE CHARACTERISTICS OF ITS TIME-COURSE CHANGE
}

\author{
NaOTOSHI OZAWA
}

F USARIC acid (5-butylpicolinic acid; hereafter abbreviated as $\mathrm{Fa}$ ), a kind of fungusproduced substances recently developed by Umezawa et al., biochemically inhibits, in vivo and in vitro, the enzymatic action of dopamine-hydroxylase $(\mathrm{DBH})$ and lowers the level of endogenous adrenaline (A) and noradrenaline (NA) in brain, heart, spleen and adrenal glands ${ }^{2,3}$ It is reported, clinically, to have antihypertensive effect and to be effective for relieving tremor and rigidity in parkinsonism. ${ }^{4}$ However, it has not yet been determined whether or not the antihypertensive effect appearing after the administration of $\mathrm{Fa}$ is mediated through the lowering of $\mathrm{A}$ and NA biosynthesis due to the inhibition of enzymatic action of DBH by this drug. A well-known example of $\alpha$-metyldopa ${ }^{6}$ can be cited here, which was once thought to achieve antihypertensive effect through inhibiting the biosynthesis of catecholamines (CA), such as A or NA, by diminishing the enzymatic action of dopa-decarboxylase, an enzyme of importance in the biosynthesis of CA. But this mode of action turned out to be rather secondary for $\alpha$-methyldopa, and it was made clear that $\alpha$-methyldopa lowers the sympathetic tone primarily by making the organism to produce false transmitter? ${ }^{7}$ Therefore, it is reasonable to surmise, as a possibility, that $\mathrm{Fa}$ may also inhibit the actions

\footnotetext{
Key Words: Fusaric Acid

Urinary Catecholamines

Dopamine-hydroxy lase

Essential Hypertension

Noradrenaline
}

of sympathetic nervous system by mechanisms other than the inhibition of DBH activity. In such a sense it is quite appropriate to examine, in details, the change in the urinary excretion of $\mathrm{CA}$ during the administration of $\mathrm{Fa}$ in hypertensive patients. Intuitively, we would expect a decreased urinary $\mathrm{CA}$ excretion, if its biosynthesis is inhibited by therapeutic doses of $\mathrm{Fa}$ (whether through an inhibited enzymatic action or other mechanisms).

The present study aims at elucidating this point more precisely by determining the urinary excretion of CA almost everyday for six successive weeks. As a control observation, another series of patients were administered with reserpine and the time-course change of the urinary CA excretion was compared. Some patients were included in both series. The influence of $\mathrm{Fa}$ on blood pressures was also compared between the $\mathrm{Fa}$ and reserpine group in order to study the antihypertensive effect of $\mathrm{Fa}$.

\section{SubJects ANd Methods}

Ten subjects were selected from hypertensive patients admitted to The Second Department of Medicine, Gifu University Hospital and a total of thirteen studies was made, (a) 7 . cases administered with $300-450 \mathrm{mg}$ daily of $\mathrm{Fa}$, (b) 3 cases with $600 \mathrm{mg}$ of $\mathrm{Fa}$, and (c) 3 control cases with $0.4 \mathrm{mg}$ of reserpine.

After hospitalization, these subjects were treated with rest and diet $(5.8 \mathrm{~g}$ daily intake of $\mathrm{NaCl}$, as a rule) so as to stabilize blood pressures,

(Received for publication, September 26,1972)

The Second Department of Medicine, Faculty of Medicine, Gifu University, Gifu (Director: Prof. Shoji Hayase)

The outline of this study was presented at the 36th Annual Meeting of Japanese Circulation Society, in Kanazawa, April, 10, 1972, and at the 45th Annual Meeting of Japanese Pharmacological Society, in Sendai, April, 29, 1972. 
TABLE I BLOOD PRESSURE AND RENAL FUNCTION OF THE 13 HYPERTENSIVE PATIENTS BEFORE THE TREATMENT WITH FUSARIC ACID OR RESERPINE

\begin{tabular}{|c|c|c|c|c|c|c|c|}
\hline Case & Diagnosis & $\operatorname{Sex}$ & $\begin{array}{r}\text { Age } \\
\text { (yrs.) }\end{array}$ & $\begin{array}{c}B P \\
(S y s / D i a s) \\
(m m H g)\end{array}$ & $\begin{array}{r}B U N \\
(m g / d l)\end{array}$ & $\begin{array}{c}\text { PSP } \\
(15 \mathrm{~min}) \\
(\%)\end{array}$ & $\begin{array}{r}\text { C. Cr. } \\
(m l / \min )\end{array}$ \\
\hline $\begin{array}{l}\text { M. I. } \\
(\mathrm{Fa} 300 \mathrm{mg})\end{array}$ & $\begin{array}{l}\text { Hypertension } \\
\text { Cerebral thrombosis }\end{array}$ & Male & 67 & $151 / 97$ & & 35 & 128 \\
\hline $\begin{array}{l}J . K . \\
(\mathrm{Fa} 300 \mathrm{mg})\end{array}$ & $\begin{array}{l}\text { Hypertension } \\
A L S \text { (suspect) }\end{array}$ & Female & 50 & $152 / 103$ & 11 & & 120 \\
\hline $\begin{array}{l}\text { F. N. } \\
\left(\begin{array}{ll}F a & 300 \mathrm{mg}\end{array}\right)\end{array}$ & $\begin{array}{l}\text { Hypertension } \\
\text { Hyperventilation syndrome }\end{array}$ & Female & 56 & $179 / 101$ & & 25 & 74 \\
\hline $\begin{array}{l}F . N . \\
(F a \quad 600 \mathrm{mg})\end{array}$ & $\begin{array}{l}\text { Hypertension } \\
\text { Hyperventilation syndrome }\end{array}$ & Female & 56 & $153 / 83$ & & 25 & 74 \\
\hline $\begin{array}{l}\text { M. G. } \\
(\mathrm{Fa} \quad 300 \mathrm{mg})\end{array}$ & $\begin{array}{l}\text { Hypertension } \\
\text { Diabetes mellitus } \\
\text { Chronic hepatitis }\end{array}$ & Male & 60 & $145 / 85$ & 6.2 & & \\
\hline $\begin{array}{l}\text { C. O. } \\
\left(F_{a} \quad 300 \mathrm{mg}\right)\end{array}$ & $\begin{array}{l}\text { Hypertension } \\
\text { Angina at rest } \\
\text { Diabetes mellitus }\end{array}$ & Female & 57 & $171 / 95$ & 9 & 25 & 70 \\
\hline $\begin{array}{l}\text { S. I. } \\
(\mathrm{Fa} 300 \mathrm{mg})\end{array}$ & $\begin{array}{l}\text { Hypertension } \\
\text { Gallbladder dyskinesia }\end{array}$ & Female & 57 & $173 / 90$ & 10 & 30 & \\
\hline $\begin{array}{l}\text { S. T. } \\
(\mathrm{Fa} 300 \mathrm{mg})^{*}\end{array}$ & $\begin{array}{l}\text { Hypertension } \\
\text { Parkinsonism }\end{array}$ & Male & 63 & $199 / 103$ & 15 & 25 & 61 \\
\hline $\begin{array}{l}\text { S. I. } \\
(\mathrm{Fa} \quad 600 \mathrm{mg})\end{array}$ & $\begin{array}{l}\text { Hypertension } \\
\text { Gallbladder dyskinesia }\end{array}$ & Female & 57 & $165 / 82$ & 10 & 30 & \\
\hline $\begin{array}{l}T . N . \\
(\mathrm{Fa} \quad 600 \mathrm{mg})\end{array}$ & $\begin{array}{l}\text { Hypërtension } \\
\text { Hyperlipemia } \\
\text { Ischemic heart disease }\end{array}$ & Male & 70 & $178 / 100$ & 14 & 26 & \\
\hline $\begin{array}{l}\text { A. O. } \\
\text { (Reserpine } 0.4 \mathrm{mg} \text { ) }\end{array}$ & $\begin{array}{l}\text { Hypertension } \\
\text { Angina at rest } \\
\text { A trial fibrillation }\end{array}$ & Female & 63 & $145 / 86$ & 15 & 23 & 94 \\
\hline $\begin{array}{l}\text { S. T. } \\
\text { (Reserpine } 0.4 \mathrm{mg})^{* *}\end{array}$ & $\begin{array}{l}\text { Hypertension } \\
\text { Parkinsonism }\end{array}$ & Male & 63 & $183 / 99$ & 15 & 25 & 61 \\
\hline $\begin{array}{l}S . M \\
\text { (Reserpine } 0: 4 \mathrm{mg})\end{array}$ & $\begin{array}{l}\text { Hypertension } \\
\text { Diabetes mellitus }\end{array}$ & Male & 53 & $143 / 87$ & & 25 & . \\
\hline
\end{tabular}

Fa: Fusaric acid.

* Fusaric acid + Trichlormethiazide $4 \mathrm{mg}$.

** : Reserpine $0.4 \mathrm{mg}$ + Trichlormethiazide $4 \mathrm{mg}$.
$B U N$ : blood urea nitrogen.

PSP: Phenolsulfonphthalein test.

C. Cr: Creatinine clearence. and then drugs were administered. When other antihypertensive drugs were employed previously, a sufficient washdown period was given. Urine was stored in bottles each containing $200 \mathrm{ml}$ of $2 \mathrm{~N}$ hydrochloric acid. Blood pressure was measured every day after laying in rest for somè time, i.e., in semi-basal state. After 1 week of control period, drug administration was continued for 4 weeks, followed by 1 week of observation period. In a case receiving $300 \mathrm{mg}$ of $\mathrm{Fa}$ and another case receiving $0.4 \mathrm{mg}$ of reserpine, trichlormethiazide was used concomitantly in daily dose of $4 \mathrm{mg}$. In these cases, trichlormethiazide has been used for fairly long time and "the blood pressure remained almost constant. Table I shows diagnoses and laboratory findings 


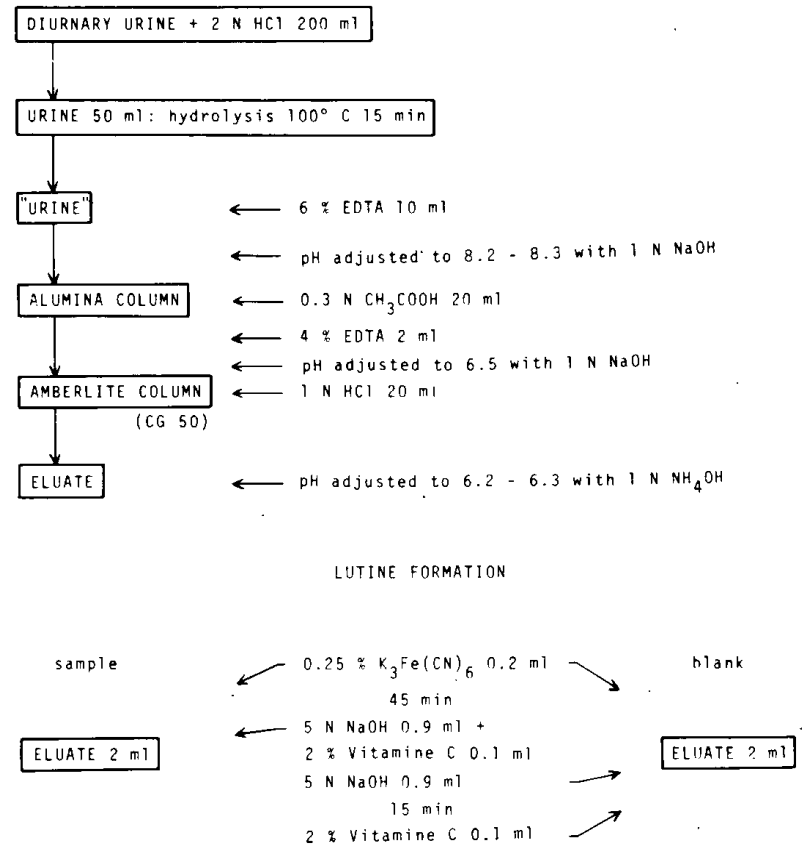

Fig.1. Schematic presentation of column chromatographic procedures to estimate adrenaline and noradrenaline in urine.

during observation. The patients ranged from 57 to 71 in age, and consisted of 5 males and 5 females; all suffered from essential hypertension with complications, but none of them had any dysfunction of kidney.

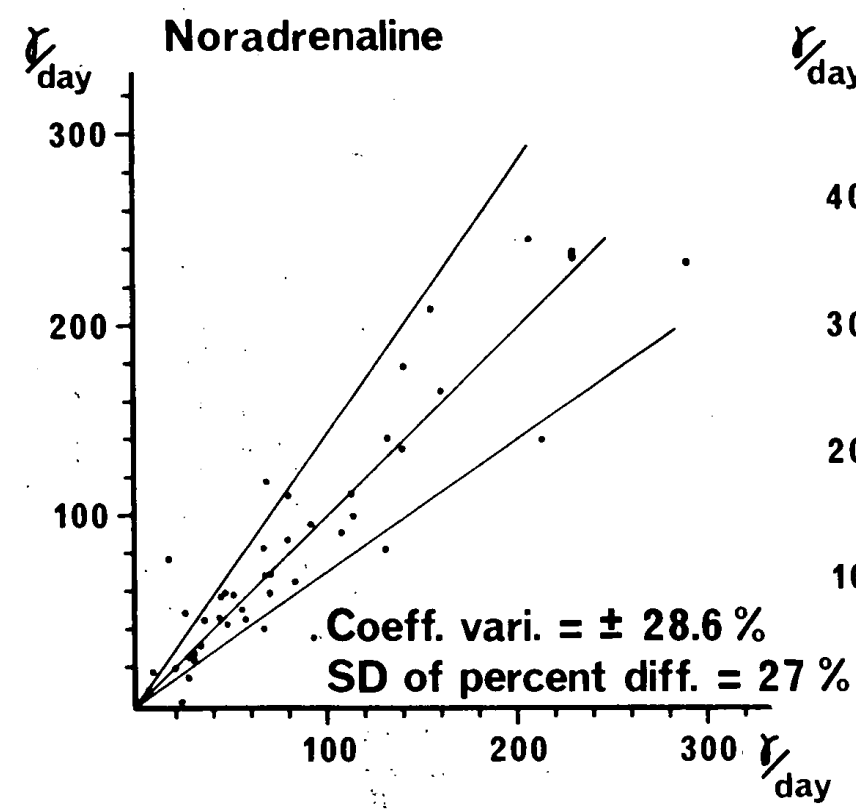

TABLE II RESULTS OF A TEST OF PRECISION OF THE MEASUREMENTS OF CATECHOLAMINES BY T.H.I. METHOD

\begin{tabular}{|c|c|c|c|}
\hline & $\begin{array}{l}\text { expected } \\
(\mu g / m l)\end{array}$ & $\begin{array}{l}\text { measured } \\
(\mu g / m l)\end{array}$ & $\%$ difference \\
\hline \multirow{2}{*}{$\begin{array}{l}\text { 1. Adrenaline } \\
\text { Noradrenaline }\end{array}$} & 0.1 & 0.130 & +30 \\
\hline & 0.1 & 0.062 & -38 \\
\hline \multirow{2}{*}{$\begin{array}{l}\text { 2. Adrenaline } \\
\text { Noradrenaline }\end{array}$} & 0.1 & 0.145 & +45 \\
\hline & 0.1 & 0.118 & +18 \\
\hline \multirow{2}{*}{$\begin{array}{l}\text { 3. Adrenaline } \\
\text { Noradrenaline }\end{array}$} & 0.1 & 0.088 & -12 \\
\hline & 0.1 & 0.099 & -1 \\
\hline \multirow{2}{*}{$\begin{array}{l}\text { 4. Adrenaline } \\
\text { Noradrenaline }\end{array}$} & 0.1 & 0.057 & -43 \\
\hline & 0.1 & 0.093 & -7 \\
\hline \multirow{2}{*}{$\begin{array}{l}\text { 5. Adrenaline } \\
\text { Noradrenaline }\end{array}$} & 0.1 & 0.113 & +13 \\
\hline & 0.1 & 0.063 & -37 \\
\hline \multirow{2}{*}{$\begin{array}{l}\text { 6. Adrenaline } \\
\text { Noradrenaline }\end{array}$} & 0.1 & 0.122 & +22 \\
\hline & 0.1 & 0.107 & +7 \\
\hline
\end{tabular}

Pure samples of catecholamines were added to human urine.

Determination of Catecholamines in the Urine

Urinary CA was measured by trihydroxyindole method. Twenty-four hour urine was diluted to a definite volume $(2000 \mathrm{ml}), 50 \mathrm{ml}$ of which was hydrolyzed at $100^{\circ} \mathrm{C}$ for $15 \mathrm{~min}$., and its total contents were measured by the method

Fig.2. Reproducibility of the determination of catecholamines by T. H. I. method, showing the result of 1 st determination along ordinate and that of the 2 nd determination, performed on a different day, along abscissa. (Explanation in text) 

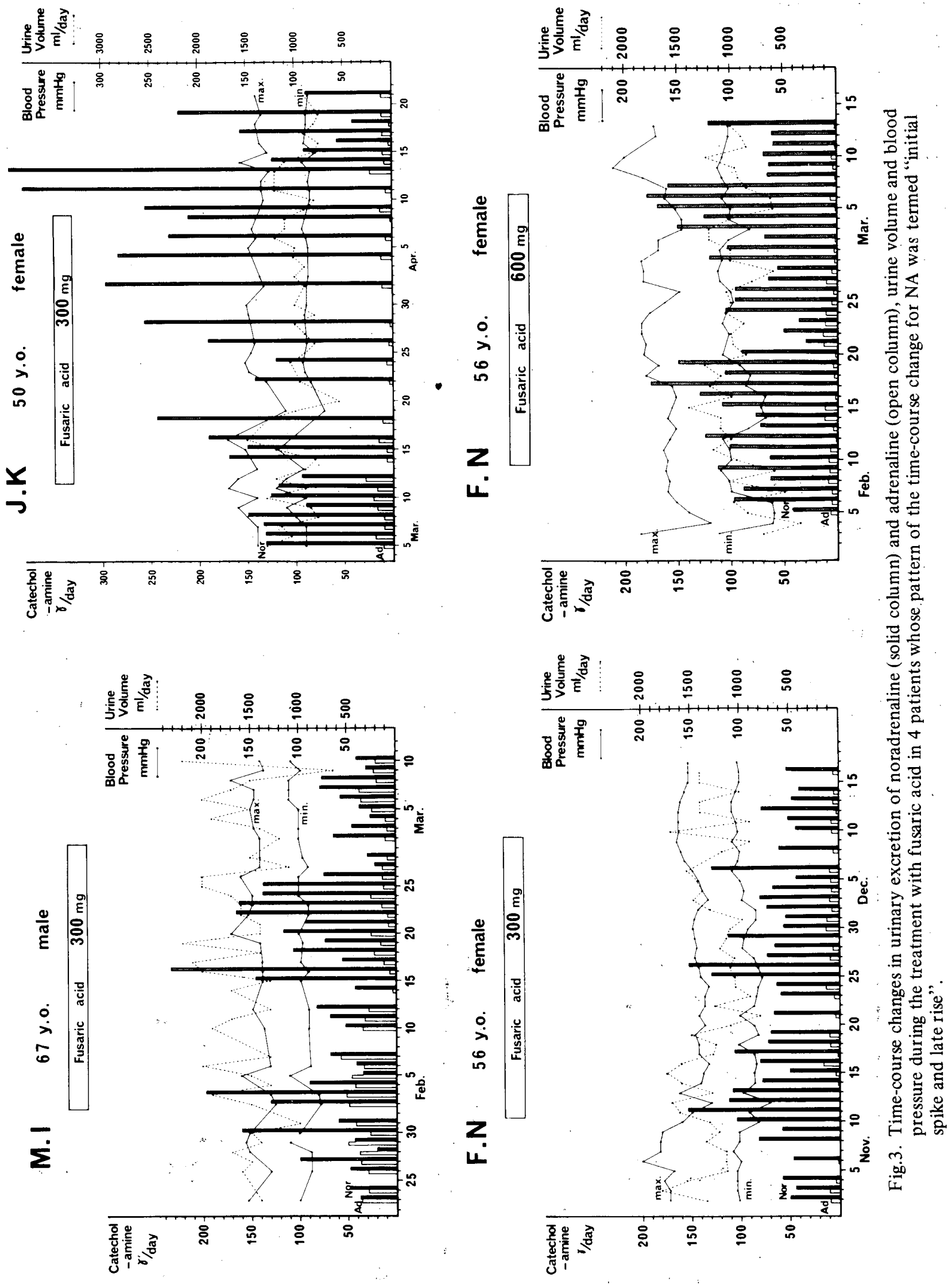

Japanese Circulation Journal Vol. 36, November 1972 
of von Euler and Lishajko, modified in that the method of Sano, Gamo and Hashimoto ${ }^{10}$ was incorporated, i.e., isolating urinary $\mathrm{CA}$ in 2 stages, with alumina column first followed by a column of Amberlite CG50. Fig. 1 illustrates the procedures used for column chromatography and oxidation of CA-containing liquid eluted from the column. For fluorescence spectro-photometer. Hitachi model 203 was used, with excitation wavelengths of $433 \mathrm{~m} \mu$ and $365 \mathrm{~m} \mu$ for A and NA respectively, and an analytical wavelength of $515 \mathrm{~m} \mu$ for both A and NA. When used as the solvent for reagents and column operation, the water was obtained first by distillation and then by careful deionization which was either supplied by the courtesy of the Second Physiology Department (Head; Prof. Masaru Sogami) or prepared by ourselves under their guidance. Calculation of urinary $\mathrm{CA}$ was as follows:

$$
\begin{aligned}
\mathrm{A} & =\frac{\mathrm{X}_{433}-0.37 \times \mathrm{X}_{365}}{9.6 \times \mathrm{H}_{\mathrm{A}}} \\
\mathrm{NA} & =\frac{1.33 \times \mathrm{X}_{365}-\mathrm{X}_{433}}{\therefore .6 \times \mathrm{HN}_{\mathrm{N}}}
\end{aligned}
$$

where:

$\mathrm{X}_{433}$ : intensity of fluorescence at analytical wavelength $515 \mathrm{~m} \mu$ for CA-containing liquid when the excitation wavelength is $433 \mathrm{~m} \mu$;

$\mathrm{X}_{365}$ : intensity of fluorescence at analytical wavelength $515 \mathrm{~m} \mu$ for CA-containing liquid when the excitation wavelength is $365 \mathrm{~m} \mu$;

0.37: ratio of fluorescence intensity of 0.1 $\mu \mathrm{g} / \mathrm{ml}$ pure NA at $433 \mathrm{~m} \mu$ to that at 365 $\mathrm{m} \mu$;

1.33: ratio of fluorescence intensity of 0.1 $\mu \mathrm{g} / \mathrm{ml}$ pure A at $433 \mathrm{~m} \mu$ to that at 365 $\mathrm{m} \mu$;

$\mathrm{HA}_{\mathrm{A}}$ : fluorescence intensity of $0.1 \mu \mathrm{g} / \mathrm{ml}$ pure A at wavelength $365 \mathrm{~m} \mu$;

$\mathrm{HN}$ : fluorescence intensity of $0.1 \mu \mathrm{g} / \mathrm{ml}$ pure NA at wavelength $365 \mathrm{~m} \mu$.

\section{RESULTS}

(1) Validity of measurements of urinary CA

In a series of preliminary tests, the accuracy and reproducibility of urinary CA measurements were examined. The results is shown in Table II and Fig.2. Six preliminary tests shown in Table II were intended to investigate the extent to which an artificial increment of the concentration of $A$ or NA in the urine, produced by adding pure $\mathrm{A}$ or NA in a concentration of $0.1 \mu \mathrm{g} / \mathrm{ml}$ can be detected by the method of determination employed. The results show a considerable scatter on both sides of the expected value $(0.1 \mu \mathrm{g} / \mathrm{ml})$, but the per cent difference between the measured and expected value averaged $+12 \pm 33 \%$ for $\mathrm{A}$ and $-7 \pm 23 \%$. for NA (mean \pm standard deviation), respectively.

Fig. 2 shows the extent of reproducibility of the measurements, examined by repeating measurements twice on different days, using the same urine samples. Ordinate gives the first CA measurements and abscissa gives the second ones.

The percentage difference between the 1st and 2nd measurements, calculated as $100(\mathrm{~S}-\mathrm{F}) / \mathrm{F} \%$, where $\mathrm{S}$ means the 2 nd measurement and $\mathrm{F}$ means the 1 st measurement, averaged $+9 \pm 89.3 \%(\mathrm{~N}=43)$ for $\mathrm{A}$ and $-3 \pm 27 \% .(\mathrm{N}=43)$ for NA, respectively (mean \pm standard deviation). Though considerable scatter is present, there is no systematic difference between the first and the second measurements. The coefficient of variation, i.e., standard deviation of the difference between the second and the first measurements divided by the mean value of the second measurements, in percentage, was $\pm 44.5 \%$ for $\mathrm{A}$ and $\pm 28.6 \%$ for NA, respectively.

(2) Changes in the urinary excretion of $\mathrm{A}$ and NA during the $\mathrm{Fa}$ administration

The effect of $\mathrm{Fa}$ on the urinary $\mathrm{CA}$ excretion, blood pressure, and urine volume is shown in Figs. 3, 4 and 5. As clearly seen from these figures, urinary NA excretion undoubtedly increased except for 2 cases. With regard to its time-course change, there were three patterns. Each figure puts the cases of the same pattern together.

Fig. 3 shows a group of cases represented by case M.I. shown in the left upper corner, where urinary NA excretion during observation ranged from 20 to $160 \mu \mathrm{g} / \mathrm{day}$, weekly average 65.5 $\mu \mathrm{g} /$ day, with systolic pressure of $140-158$ $\mathrm{mmHg}$ and diastolic pressure of $88-100 \mathrm{mmHg}$, or, weekly averages of $151 \mathrm{mmHg}$ sýstolic and 97 $\mathrm{mmHg}$ diastolic. After the start of the Fa therapy, urinary NA excretion increased from the 1st days, and on the 2nd day, there was a spike-like increase up to $197.7 \mu \mathrm{g} /$ day. Blood pressure showed a transient decrease to 124 $\mathrm{mmHg}$ systolic and $78 \mathrm{mmHg}$ diastolic on the $1 \mathrm{st}$ day, and 130 and $88 \mathrm{mmHg}$ on the 2 nd day, as compared with the control period. From the 3rd day, the once increased urinary NA excretion 


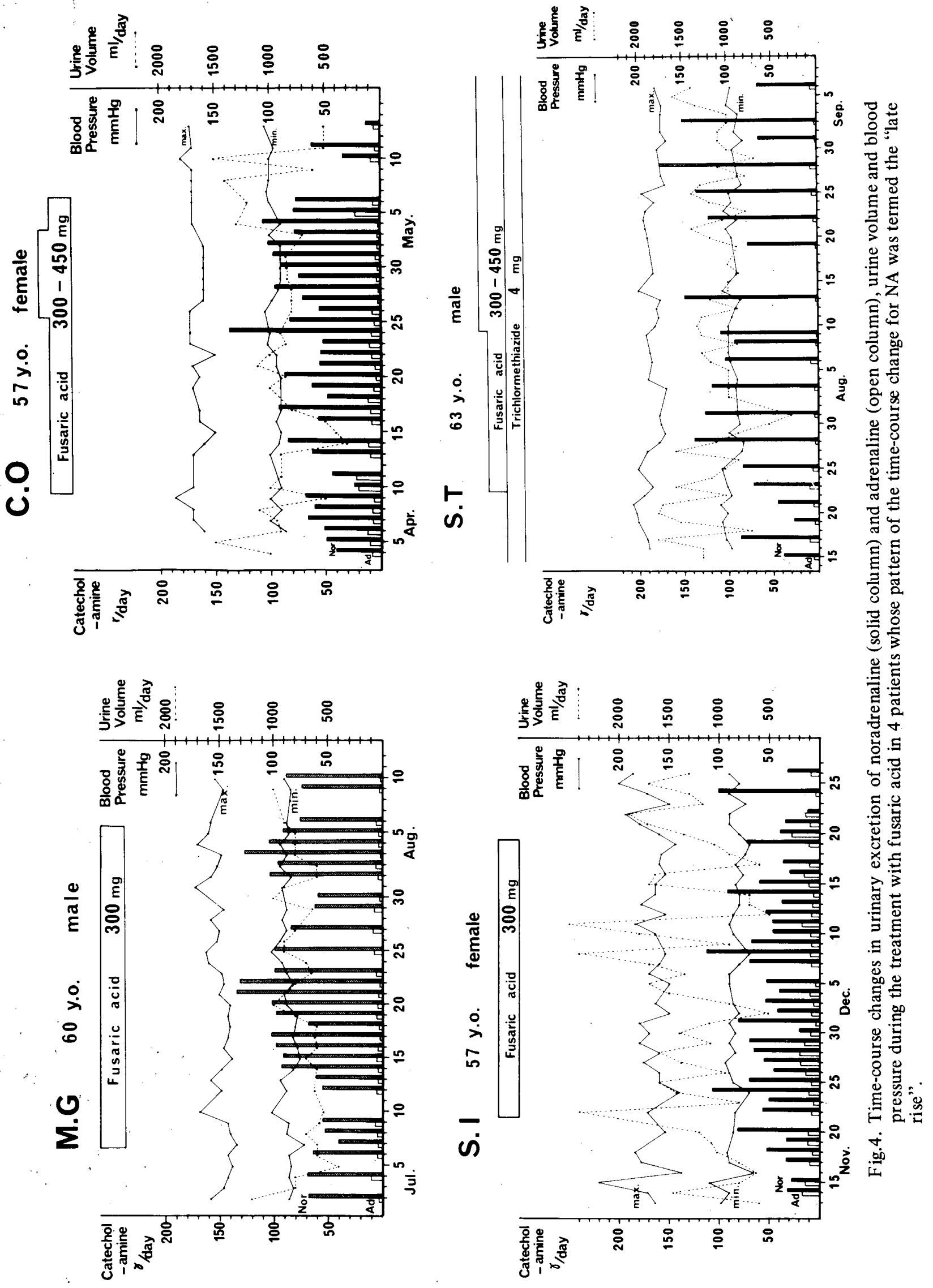

Japanese Circulation Journal Vol. 36, November 1972 


\section{S.I 57 y.o. female}

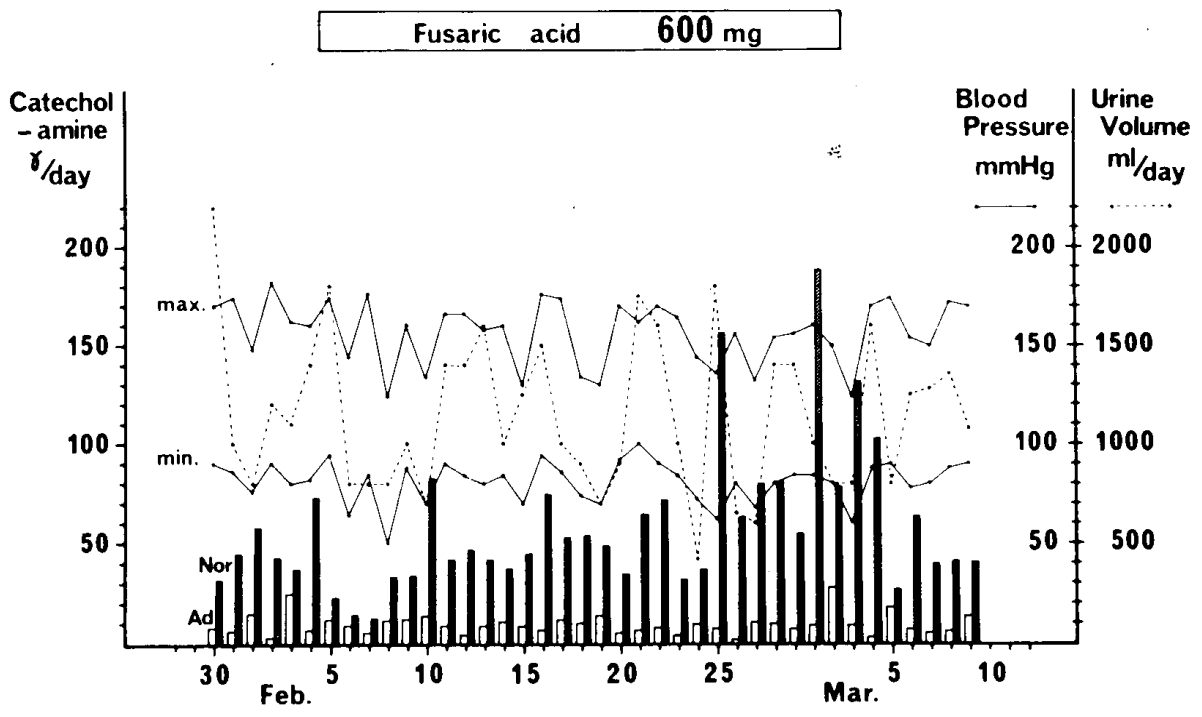

T.N 70 y.o. male

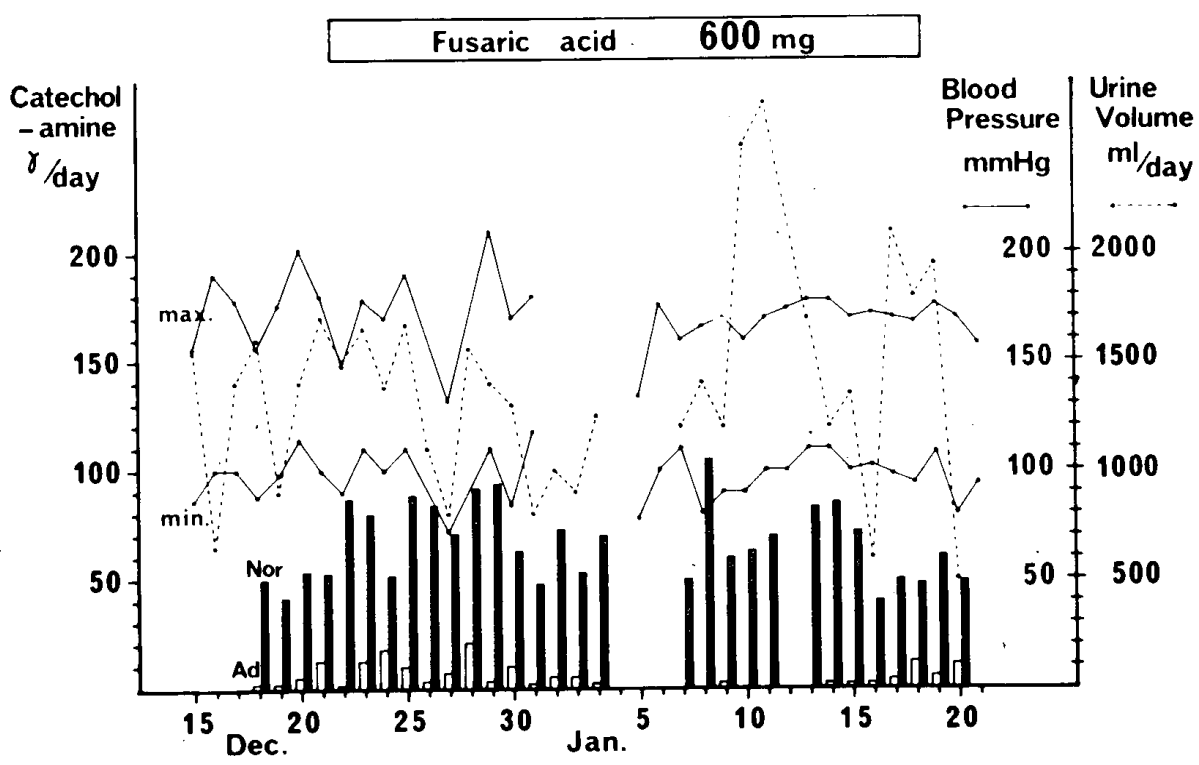

Fig.5. Time-course changes in urinary excretion of noradrenaline (solid column) and adrenaline (open column), urine volume and blood pressure during the treatment with fusaric acid, in 2 patients whose pattern of the time-course change for NA was termed "minimal change". Urinary excretion of NA (solid column) showed two spikes towards the end of the fusaric acid therapy in case S. I., but no significance was attached to these two spikes, because these spikes were of just one-day-duration.

regressed, and during the succeeding 10 days urinary NA excretion remained the same as that in the control period, i.e., $30-90 \mu \mathrm{g} /$ day. Neither systolic nor diastolic pressure showed any change from the control period. From the 12 th day of $\mathrm{Fa}$ administration urinary NA excretion again increased up to $55-230 \mu \mathrm{g} /$ day, averaging 110 , an increase by $80 \%$ over the control level, which lasted for the entire remaining period of the $\mathrm{Fa}$ administration. During this period the average systolic pressure was $144 \mathrm{mmHg}$ and the average diastolic pressure was 94 , only a slight decrease of systolic pressure as compared with the control period. During the $1 \mathrm{st}$ week after the cessation of Fa therepy, the urinary excretion was $23.4-77.8$ $\mu \mathrm{g} /$ day, averaging 54.4 , a slight decrease from the 

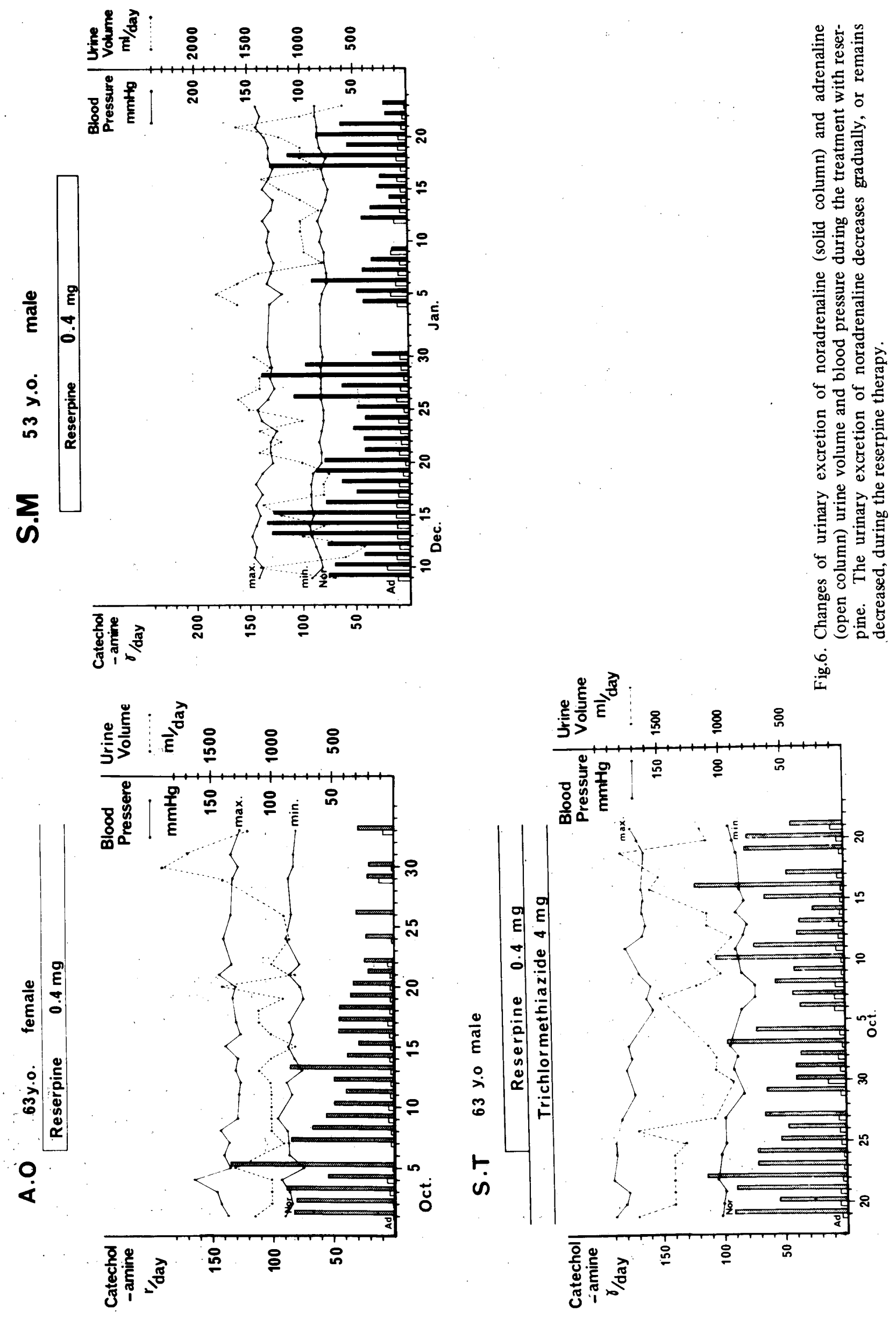
Fusaric Acid on Urinary Excretion of Catecholamine

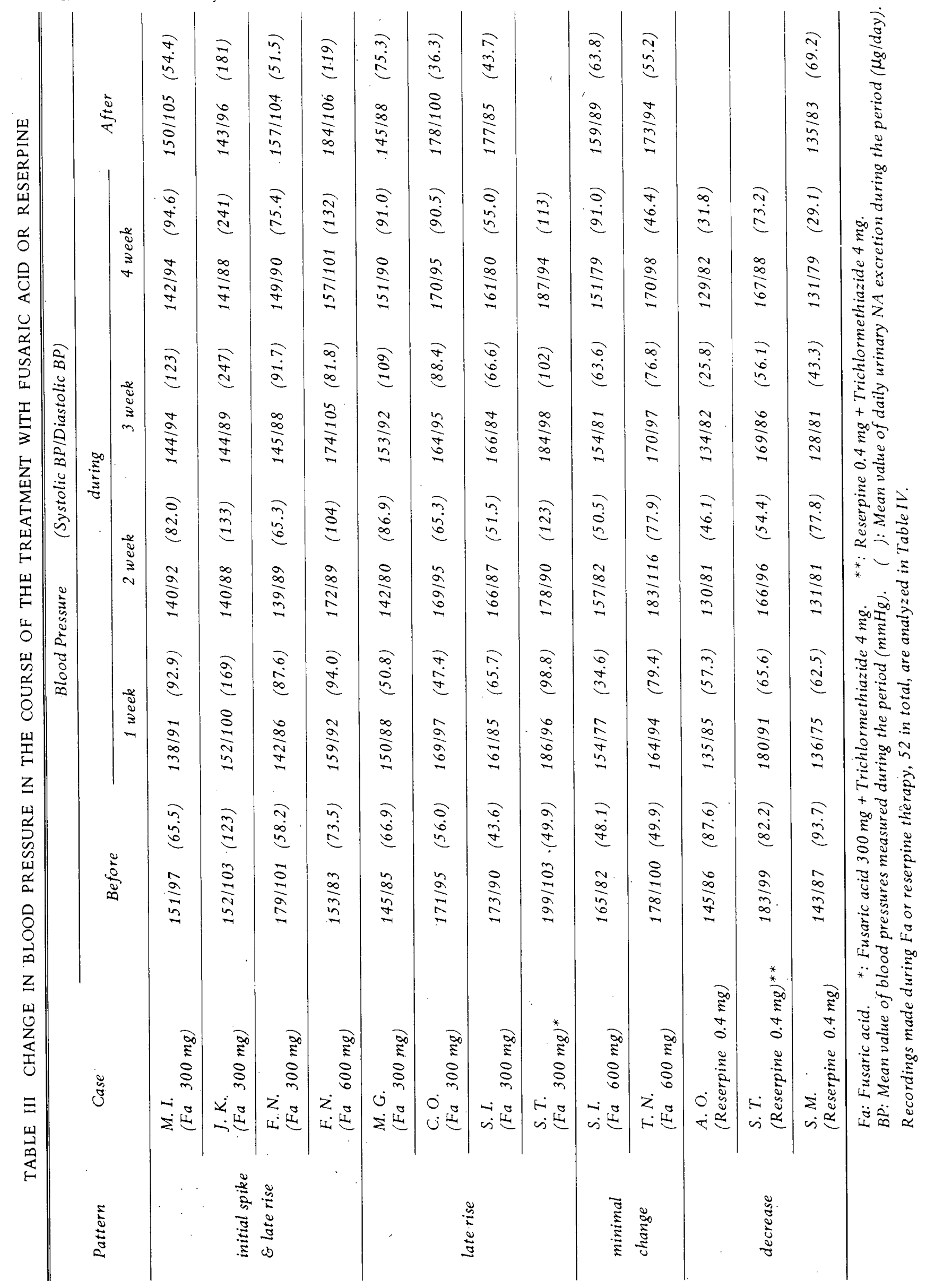


level prevailing before the administration of $\mathrm{Fa}$. Average blood pressure was $150 \mathrm{mmHg}$ systolic and 105 diastolic; urinary NA excretion and blood pressure became almost the same as in the control period. A pattern, characterized by an initial "spike"-like rise of urinary NA for $1-8$ days, followed by a temporary return to the control level for about 10 days, and then a late rise which lasts longer, can be designated as a pattern of "initial spike and late rise". Fig.3 shows 4 cases fitting to this pattern, consisting of 3 cases receiving $300 \mathrm{mg}$ of $\mathrm{Fa}$ and 1 case receiving $600 \mathrm{mg}$ of $\mathrm{Fa}$.

Averaging the results of the cases with the "initial spike and late rise" pattern, some characteristics of the time-course changes in urinary NA excretion during Fa therapy became evident; "initial spike" appeared within the first 8 days ( $4.5 \pm 3.5$ : mean $\pm S D$ ), but "post-spike dip" occurred on $8-13$ th day $(11 \pm 2.2)$, indicating a fairly fixed point of time when this "dip" (return to the control) occurs; "start of the late plateau" occurred on the 14-15th day (15 \pm 0.8$)$, again indicating a very fixed nature of the time when the "late rise" starts. As to the urinary A excretion, no such a tendency could be found.

Fig. 4 shows a group of cases represented by case M.G. shown in the left upper corner. Sketches of the case M.G. are as follows. In the control period, the daily urinary NA excretion was $63.5-68.5 \mu \mathrm{g} / \mathrm{day}$, averaging 66.9. Systolic pressure was $158-138 \mathrm{mmHg}$ and diastolic $82-86$, averaging 145 and 85 , respectively. For 8 days after the start of the administration, urinary NA excretion was $40-60.4 \mu \mathrm{g} / \mathrm{day}$, averaging 50.8 , that is, almost unchanged from the control period. The average blood pressure were 150 mmHg systolic and 88 diastolic. On the 9 th day of $\mathrm{Fa}$ administration onwards, the urinary NA excretion showed a continuous rise up to $60.1-123 \mu \mathrm{g} /$ day, averaging 96.3 , i.e. about $40 \%$ higher than the control level. Average systolic pressure was $150 \mathrm{mmHg}$ and diastolic $88 \mathrm{mmHg}$. After discontinuing $\mathrm{Fa}$ administration the urinary NA excretion stayed at the level of 73.6$87.6 \mu \mathrm{g} /$ day averaging 75.4. Blood pressures were $145 \mathrm{mmHg}$ systolic and 88 diastolic. Thus urinary NA excretion during the first 10 days of the Fa therapy was almost the same as in the control period, i.e., no "spike" appered in this period and it was after about 10 days that the urinary NA excretion became continuously high. This pattern will be named as the "late rise" pattern. The results of 4 cases showing this pattern are shown in Fig. 4; all these cases received $300 \mathrm{mg}$ of Fa daily.

Averaging the results of the cases with the "late rise" pattern, a characteristic of the time-course change in the urinary NA excretion during Fa therapy was found. "Start of late plateau" appeared on the 7-8th day $(7.8 \pm 0.4$ : mean \pm SD) after the start of the administration of $\mathrm{Fa}$, indicating a very fixed nature of the time when the "late rise" starts. Not a single case treated with a daily dose of $600 \mathrm{mg} \mathrm{Fa}$ showed this pattern. Urinary A excretion did not show such a pattern.

Fig. 5 shows 2 cases which are grouped together for a reason to be stated below. During the control period the case S.I. excreted $32.3-73.3 \mu \mathrm{g} /$ day of $\mathrm{NA}$ in urine, averaging 48.1. Blood pressures were $148-170 \mathrm{mmHg}$ systolic and 70-90 diastolic, averaging 165 and 82 , respectively. In the 1 st week of the $\mathrm{Fa}$ administration, urinary NA excretion was 12.7-82.7 $\mu \mathrm{g} / \mathrm{day}$, averaging 34.6, a slight decrease below the control level. Blood pressures were $124-174 \mathrm{mmHg}$ systolic and 50-94 diastolic, averaging 154 and 77, respectively. In the 2nd and 3rd weeks no marked change of urinary NA excretion was found, with $31.7-71.7 \mu \mathrm{g} /$ day, averaging 57.5. Blood pressures were $130-170 \mathrm{mmHg}$ systolic and $70-94 \mathrm{mmHg}$ diastolic. In the 4 th week urinary NA excretion increased to $31.7-188.6 \mu \mathrm{g} /$ day, averaging 91.0 $\mu \mathrm{g} /$ day. Blood pressures were $124-174 \mathrm{mmHg}$ systolic and 60-90 diastolic, averaging 159 and 89 , respectively. An example of a case like this, in which, in spite of slight changes in urinary NA excretion during the $\mathrm{Fa}$ therapy, no significant change occurred throughout the whole period, is also shown in Fig. 5. Both cases received $600 \mathrm{mg}$ of $\mathrm{Fa}$ daily. No definite pattern was found in the urinary A excretion.

As a whole, the relation between the dosage and the pattern of the urinary NA excretion was as follows; out of 10 cases treated with $\mathrm{Fa}$, all cases receiving $300 \mathrm{mg}$ and 1 case receiving 600 $\mathrm{mg}, 8$ in total, showed the first two patterns, and 2 cases receiving $600 \mathrm{mg}$ showed the last pattern. No definite relation could be found between the urine volume and the pattern of urinary NA excretion, or blood pressure change.

(3) Time-course change on the urinary NA excretion during the reserpine therapy

Fig. 6 shows results obtained in 3 cases. The case A.O. shows a pattern of an abrupt fall followed by a gradual decrease, but cases S.T. 


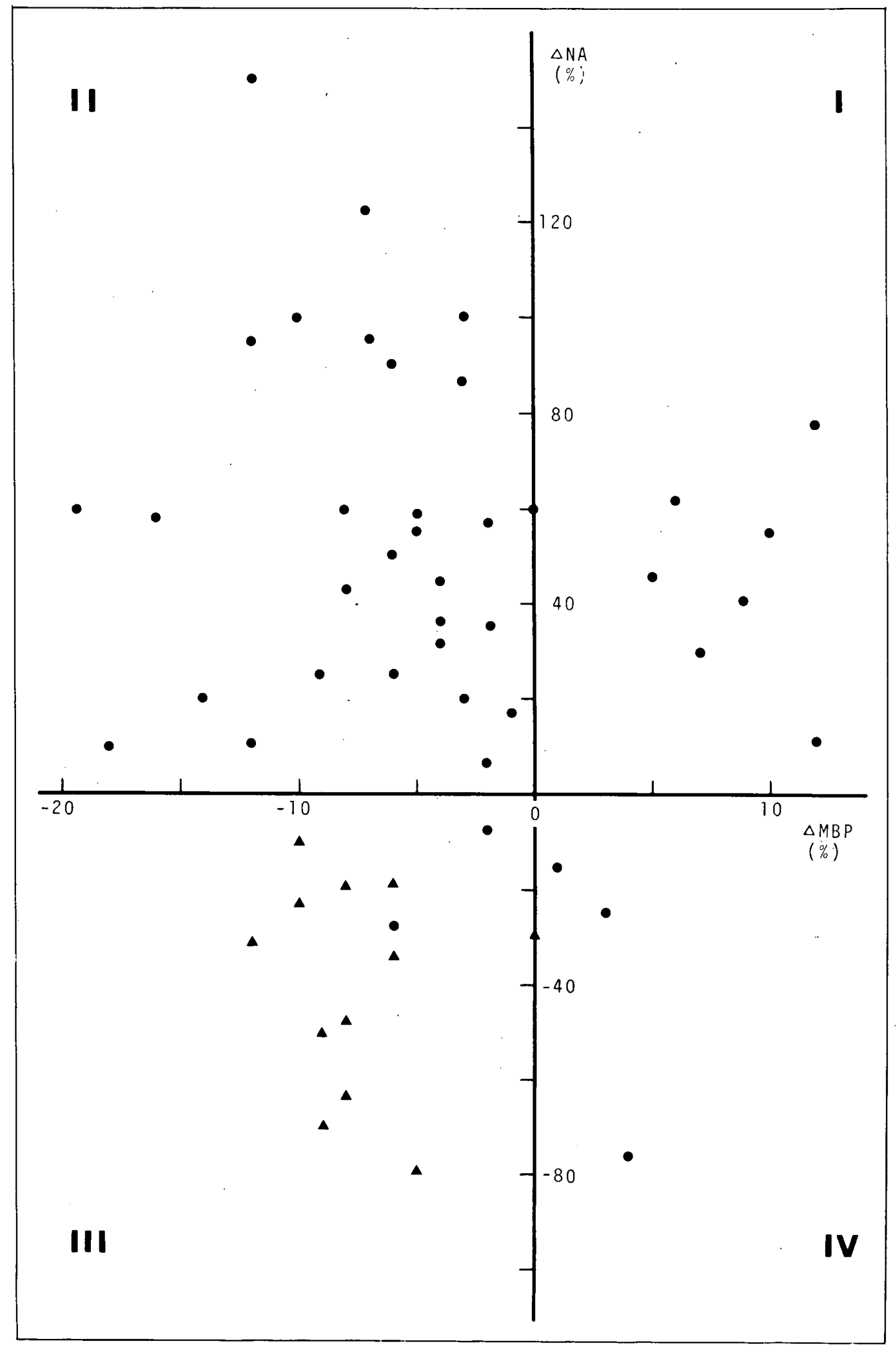

- : Fusaric acid therapy.

A : Reserpine therapy.

$\triangle M B P:$ per cent change of mean blood pressure from the control value.

$\triangle \mathrm{NA}$ : per cent change of urinary NA from the control value.

Fig.7. Scatter diagram of per cent changes of mean blood pressure and urinary NA excretion from the control value, studied at weekly-intervals during $\mathrm{Fa}$ or reserpine therapy. 


\section{Reserpine}

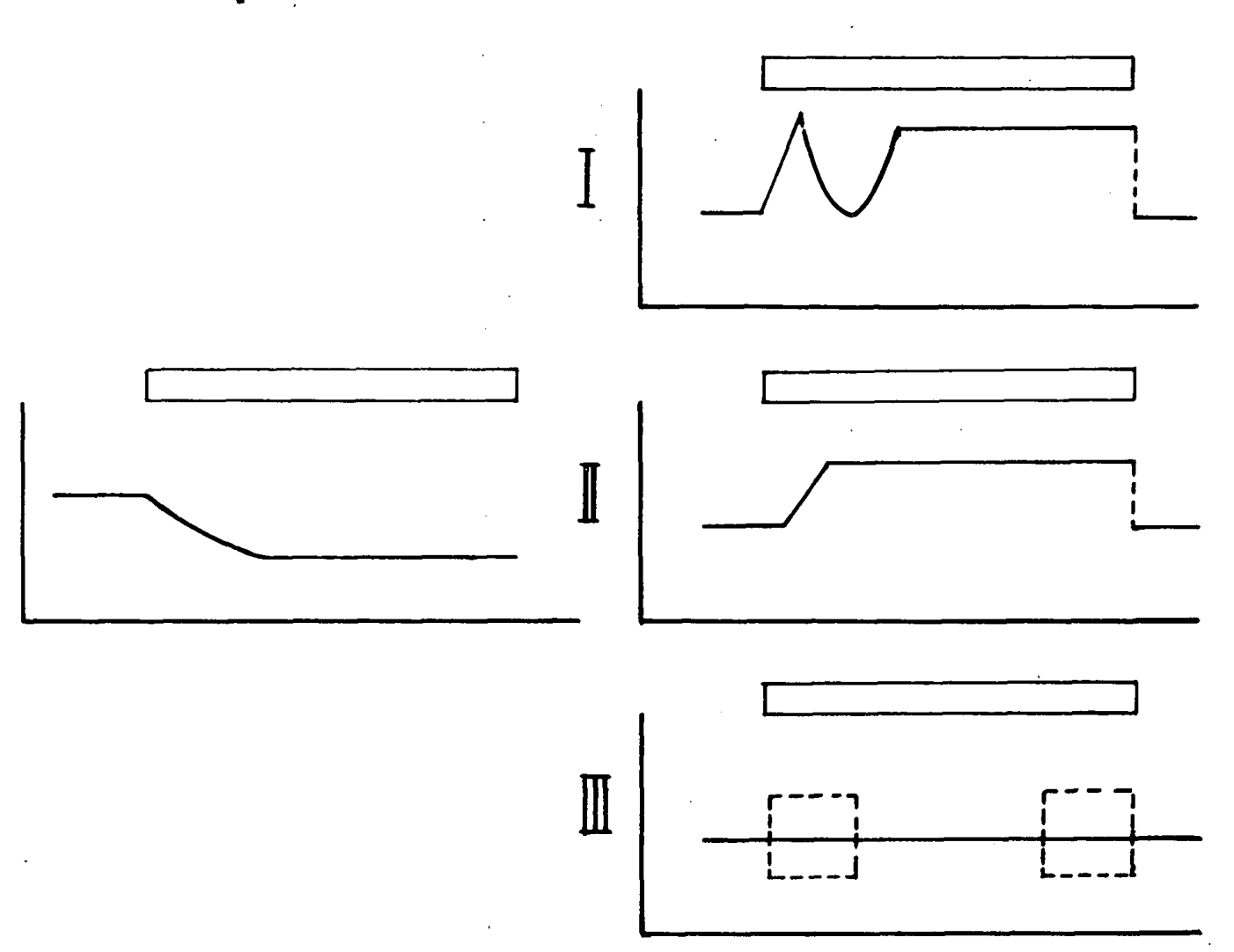

\section{Fusaric acid}

Fig.8. Schematic illustration of the pattern of urinary noradrenaline excretion during the treatment with fusaric acid or reserpine. For fusaric acid, pattern I refers to the "initial spike and late rise", pattern II refers to the "late rise", and pattern III refers to "minimal change". Rectangles in broken line, drawn for pattern III, indicate minor increase or decrease of urinary NA early or late during the administration of Fa. . and S.M. reveal a pattern of continual decrease with a few peaks comparable with the control period. In short, the pattern of the urinary NA excretion is clearly different from that observed during the Fa administration.

(4) Relation between the blood pressure change and urinary NA excretion pattern

As shown in Figs.3, 4 and 5, there are those showing a gradual decrease of blood pressures regardless of $\mathrm{Fa}$ dosage or urinary $\mathrm{NA}$ or $\mathrm{A}$ excretion pattern, or those without any significant change, or with slight increase, in the blood pressure. Let us examine these phenomena statistically.

The weekly averages of systolic and diastolic pressures before the administration of $\mathrm{Fa}$, in the $1 \mathrm{st}, 2 \mathrm{nd}, 3 \mathrm{rd}$, and 4 th week of the administration, and after the cessation of the Fa therapy, are given in Table.III. In "initial spike and late rise" group, blood pressures in cases M.I. and J.K. showed a gradual fall, case F.N. (300 mg) a gradual fall followed by a tendency to rise and case F.N. $(600 \mathrm{mg})$ a gradual rise. Case M.I. and J.K., which showed a fall during administration, showed further fall after the discontinuance of Fa therapy. Case C.O. showed almost no change before, during, and after the administration of Fa. Cases S.I. and S.T. showed a slight fall. The 2 cases with "minimal change" pattern, S.I. and T.N., showed a slight fall of blood pressure. So far as 4 week treatment is concerned, 7 out of 10 cases showed a slight depressor tendency, 2 cases showed a pressor tendency, and 1 case remained unchanged. Fig.7 shows per cent changes of urinary NA excretion plotted against per cent changes of the mean blood pressure. These changes were measured between the control period and each week during the Fa or reserpine therapy. As is evident from Fig.7, most plots for $\mathrm{Fa}$. therapy are concentrated in a quadrant indicating a lowered mean blood pressure and increased urinary NA excretion. However, there 


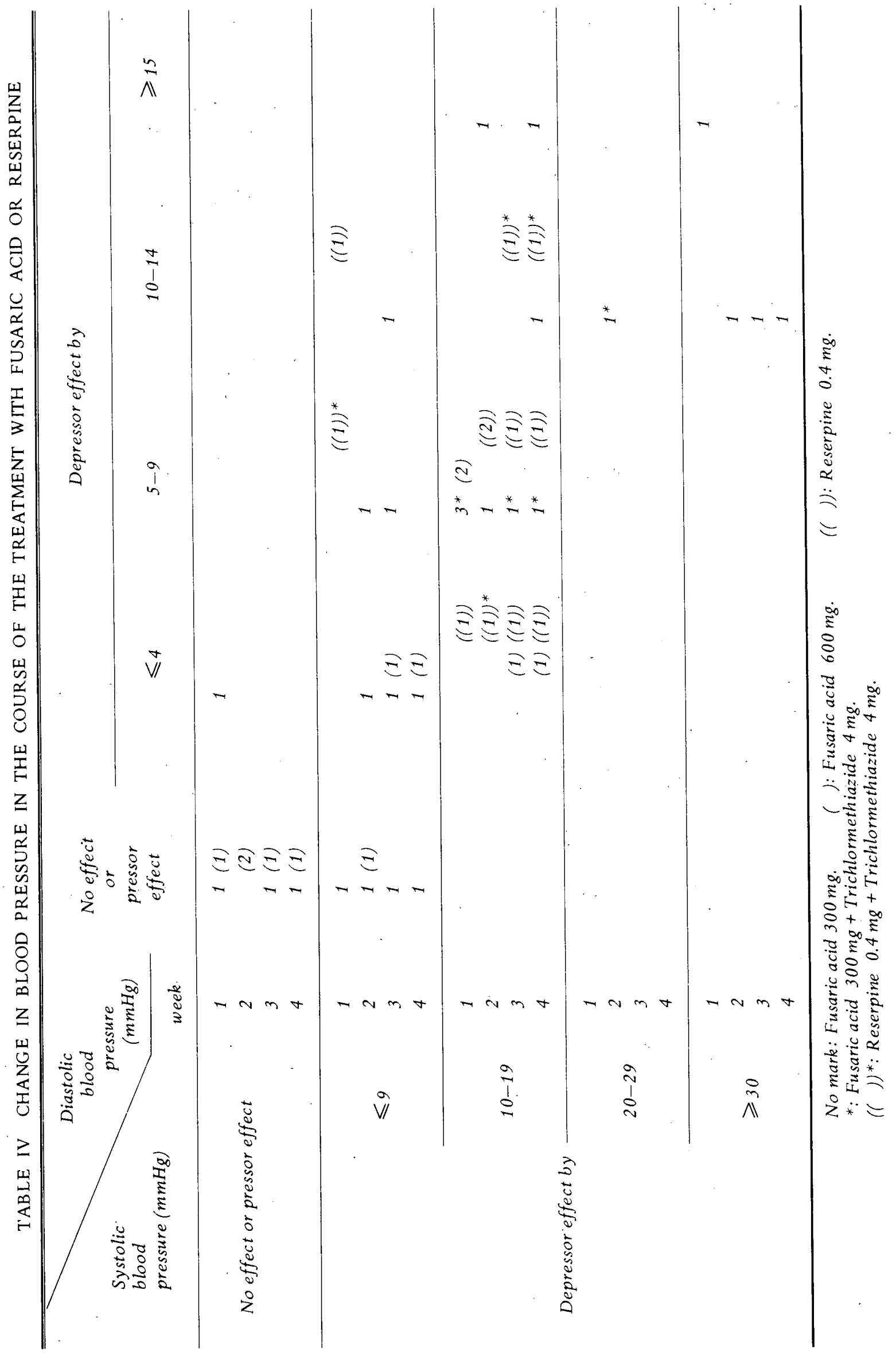

Japanese Circulation Journal Vol. 36, November 1972 


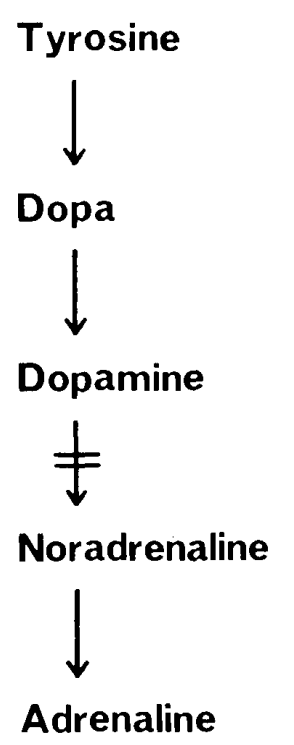

Tyrosine<smiles>CC</smiles>

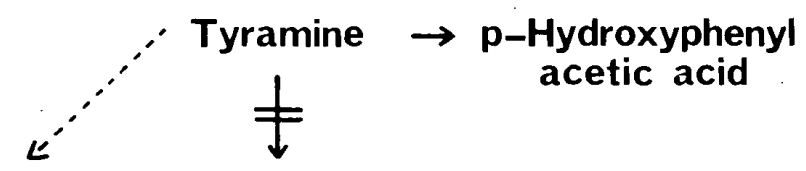

Dopamine Octopamine $\rightarrow$ p-Hydroxymandelic

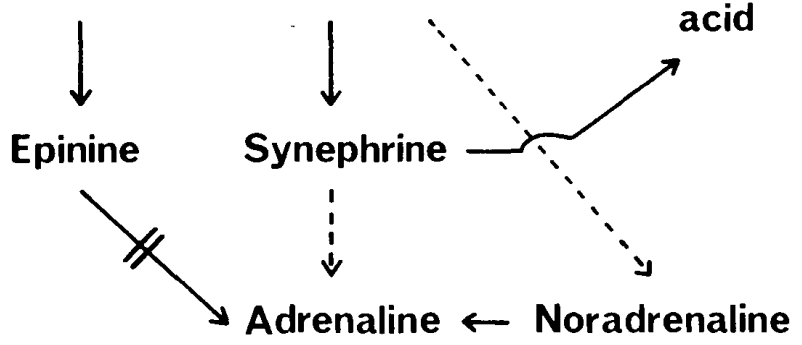

\section{$\longrightarrow$ : inhibition of dopamine beta-hydroxylase by fusaric acid \\ ( M.Sandler and C.R.J.Ruthven ) Prog. Med. chemi. 1969}

Fig.9. Pathways of biological synthesis of catecholamines.

is no correlation between the blood pressure change and the change in urinary excretion of NA, the coefficient of correlation $r=0.1$ for plots for $\mathrm{Fa}$ therapy. On the contrary, in the patients treated with reserpine, a gradual fall of blood pressure was found in all cases, particularly remarkably in case A.O.. In order to further examine the depressor effect of $\mathrm{Fa}$, weekly-averaged blood pressures, 52 in total as in Table III, were classified according to the degrees of depression from the averages of control period, which were $\leqq 9,10-19,20-29$, and $\geqq 30 \mathrm{mmHg}$ for systolic pressure, and $\leqq 4,5-9$, $10-14$, and $\geqq 15 \mathrm{mmHg}$ for diastolic pressure, as in Table IV. There were 8 occasions of no effect in systole and diastole. Identifying depressor responses by more than $10 \mathrm{mmHg}$ systolic and more than $5 \mathrm{mmHg}$ diastolic with "effect", there were 16 effective instances of Fa therapy.

\section{Discussion}

The behaviors of urinary NA excretion during the $\mathrm{Fa}$ therapy were already shown in Figs.3, 4, and 5. They are summarized schematically in Fig. 8. Scarcely any change was recognized in the urinary A excretion. From Fig. 8 one may raise, at least, the following 3 questions.

(1) what is the nature of initial spike of urinary NA excretion?

(2) what is the nature of late rise of urinary

NA excretion?

(3) what is the relation between the blood pressure and urinary NA excretion?

These will be discussed in the following sections.

(1) The nature of the "initial spike" of urinary NA excretion

Though DBH is not a rate-limiting enzyme in the biosynthesis of $\mathrm{NA}^{1}{ }^{1}$, pharmacological interference with DBH activity results in an inhibited NA biosynthesis in tissue ${ }^{2,13} \mathrm{Fa}$ inhibits the enzymatic action of $\mathrm{DBH}$ primarily by chelating the $\mathrm{Cu}$ ion of $\mathrm{DBH}^{3}$ In 4 out of 10 cases, there was a spike-like rise of NA excretion in urine at the early stage of the $\mathrm{Fa}$ therapy. This rise may be attributed to several mechanisms, such as acceleration of NA production, inhibition of re-uptake, inhibition of break-down to "subordinate" substances, etc., but the most plausible explanation is that this was caused by a release of NA, on the ground of timing and persistence, without regard to the result of animal experiments? The fact that the urinary NA excretion increased spike-wise also suggests that, owing to its dose, Fa could not exert any inhibitory effect on the enzymatic activity of $\mathrm{DBH}$, an inherent 
biochemical action of $\mathrm{Fa} !^{-3}$ In fact, among 3 cases treated with the daily dose of $600 \mathrm{mg}$ of $\mathrm{Fa}$, only one showed "initial spike" and the other two cases showed the pattern of "minimal change". Such a suggestion must be examined in the future. Other possibilities may be invoked to explain the "initial spike", such as, (a) a direct effect to release NA, though its mechanism is not yet known, or (b) release of NA by the following chain of events: inhibition of $\mathrm{DBH}$ by $\mathrm{Fa} \rightarrow$ accumulation of CA-like substances, such as tyramine, epinine $\rightarrow$ release of $\mathrm{NA}^{14-17}$ But if one admits that the inhibition of enzymatic action took place with therapeutic doses of $\mathrm{Fa}$ used, DBH, acting at the step from tyramine to norsynephrine, must also be inhibited by $\mathrm{Fa}^{2}$, as shown in Fig. 9, and the production of norsynephrine is inhibited. Similarly, the pathway dopamine $\rightarrow$ epinine $\rightarrow$ adrenaline should be also inhibited. ${ }^{7}$ Then urinary NA excretion should be decreased. On the contrary urinary NA excretion increased. Therefore, the initial spike-like release of CA in urine could hardly be understood by inhibition of DBH enzymatic action by $\mathrm{Fa}$. Moreover, as it is believed that the activity of DBH in adrenal grands increases when CA is released, 18,19 it is unlikely that our dosage of $\mathrm{Fa}$ inhibits $\mathrm{DBH}$ enzymatic activity, rather, it seems to increase $\mathrm{DBH}$ activity. If one regards $\mathrm{Fa}$ as $\mathrm{CA}$ releaser, one must compare $\mathrm{Fa}$ with reserpine, a representative $\mathrm{CA}$ releaser. It is known that when reserpine is administered, NA is deaminated before entering the circulating blood; NA in blood does not increase, ${ }^{4}$ and as the results urinary excretion of NA decreases. In our 3 cases of reserpine-administration a lowered urinary NA excretion was obtained. It is possible that NA is released and enters into blood without being metabolized, because, in case of Fa, urinary NA excretion increased "spike-wise" in a short time after the start of the therapy. In this sense, also, the mechanism of the action of $\mathrm{Fa}$ seems to differ from that of reserpine.

(2) The nature of the "late rise" of urinary NA excretion

The continuous increase of urinary NA excretion observed in the majority of cases at the late stage of the $\mathrm{Fa}$ therapy cannot be explained by either NA release or inhibition of re-uptake into the sympathetic endings, because this "late rise" extended over a long period of time. If one considers Fa as a DBH inhibitor, it is of course difficult to explain the observed "promotion" of
NA synthesis. The continuous increase of urinary NA excretion at this stage should be probably ascribed to an increased CA production. According to Wurtman, ${ }^{0}$ "for any particular day, it can be assumed that the amount of catecholamine synthesized is roughly equal to the amount of norepinephrine, epinephrine and their metabolites excreted into the urine". "At the present time, sympathetic nervous and adrenomedullary activities probably are still best estimated by measurement of urinary norepinephrine and epinephrine although the interpretation of such data is complicated by the fact that the fraction of active material metabolized or rebound before its excretion does not necessarily remain constant when there is a change in its rate of release". It may be surmised that, with $300 \mathrm{mg}$ given everyday, $\mathrm{Fa}$ did not produce the inhibition of NA synthesis by inhibiting the DBH activity; it rather seems that $\mathrm{Fa}$ acted to stimulate the NA production. If $\mathrm{Fa}$ inhibits, as mentioned above, the enzymatic action of DBH in the process of NA biosynthesis, the accumulaiton of dopamine and DOPA, precursor of NA, is expected. If this is the case, it is possible that the accumulated precursors are expected in the urine and they influence the estimation of the urinary NA. To elucidate this point, a preliminary experiment was performed by adding pure dopamine or DOPA in a contaminating $2 \mu \mathrm{g} / \mathrm{ml}, 8 \mu \mathrm{g} / \mathrm{ml}$, respectively, to urine samples containing NA in a concentration of $0.06 \mu \mathrm{g} / \mathrm{ml}$, and these "contaminated" urine samples were examined for NA by T.H.I. method. The estimated value of NA turned out to be $0.05 \mu \mathrm{g} / \mathrm{ml}$ in the presence of dopamine indicating that the determination of NA by this method is scarcely affected by the concomitant presence of dopamine; the estimated value of NA was $0.08 \mu \mathrm{g} / \mathrm{ml}$, indicating a slight increase within experimental errors, described earlier in this paper, in case of DOPA. Contamining effects of the metabolites of catecholamines has thus been ruled out at least for dopamine and DOPA.

In a separate series of preliminary study, using two patients, 4 bouts of "spike-like" increase in the urinary excretion of NA were produced by 4 periods, of 3-4 day-duration each, of the administration of $\mathrm{Fa}$. Concomitant with the increased urinary NA excretion, urinary excretion of vanillyl mandelic acid (VMA) tended to increase, e.g. averaging $7.3 \mathrm{mg} /$ day in contrast with $4.2 \mathrm{mg} /$ day found during the control period. Such an increase in the urinary VMA, one of the 
metabolites of NA, concomitant with an increase in the urinary NA excretion, suggests an accelerated production of NA under the influence of $\mathrm{Fa}$.

Obviously, the urinary NA, measured by the present method using hydrolysis, included its conjugate form, i.e., inactive NA, and this may be the reason, in parts, why the vascular smooth muscle apparently escaped the vasoconstrictor effect of the newly synthesized norepinephrine, a conclusion suggested by the observed slight depressor effect of the $\mathrm{Fa}$ therapy and the presumed augmentation of NA biosynthesis. Alternatively, the suggested "acceleration" of NA production may reflect the organism's homeostatic effort to maintain its blood pressure in face of the depressor effect of Fa therapy. However, further investigation into this point is needed.

(3) Relationship between the blood pressure and urinary NA excretion

The time-course change in blood pressure and urinary NA excretion in individual cases receiving Fa was already shown in Figs. 3, 4 and 5 and Table III. Generally, the urinary NA excretion of hypertensive patients is mostly in the normal range, and DeQuattro ${ }^{21}$ reported that in $90 \%$ of 175 hypertensive patients it was in normal range. But it was also pointed out that when the blood pressure of hypertensive patients was lowered by controlling salt intake and/or administration of thiazide, those patients increased CA excretion as if attempting to maintain homeostasis 22 In 8 cases of $\mathrm{Fa}$ administration, an increase in urinary excretion of NA was recognized, exemplified remarkably by the "initial spike", but no significant fall of blood pressure was found at that time. Therefore, no direct relation was found between the blood pressure change and urinary NA excretion, and the observed increase of urinary NA excretion may not be ascribed to a feed-back mechanism due to an induced hypotension.

As we have seen, the result obtained so far suggests that the therapeutic doses of $\mathrm{Fa}$ act to release NA and cause acceleration of the production of NA, but it seems necessary to measure urinary VMA, in end-product of NA and free $\mathrm{NA}$, before drawing the final conclusion as to the action of $\mathrm{Fa}$ on the $\mathrm{Ca}$ metabolism.

As shown in Tables III and IV, Fa did not appeare to be as effective as reserpine in its antihypertensive effect. However, the author wants to refrain from expressing his final view on its antihypertensive effect of this drug on the basis of the present results, because the number of subjects is small and further examination of the dosage is necessary.

\section{SUMMARY}

To 10 hypertensive patients fusaric acid, a dopamine- $\beta$-hydroxylase inhibitor, was administered orally in daily dose of $300-600 \mathrm{mg}$ for 4 weeks, and the change of urinary catecholamines was examined almost every day. The results obtained were as follows.

(1) There were three patterns of the time-course change in the urinary excretion of noradrenaline during the fusaric acid therapy, i.e., (i) that of "initial spike-like increase followed by a continuous increase throughout the later stage", found in 3 cases receiving $300 \mathrm{mg} /$ day dose and 1 case receiving $600 \mathrm{mg} /$ day, (ii) that of "late rise", i.e., a continuous rise throughout the later stage, seen in 4 cases receiving $300 \mathrm{mg} / \mathrm{day}$, and (iii) that of "minimal change", seen in 2 cases receiving 600 $\mathrm{mg} /$ day. These observations formed a sharp contrast with the fact that, during the administration of reserpine, urinary noradrenaline excretion was moderately to severely decreased.

(2) Urinary adrenaline excretion did not change with the administration of fusaric acid.

(3) No definite relation was found between the cnages in urinary noradrenaline excretion and changes in blood pressure during the fusaric acid therapy.

In conclusion, it is suggested that a small amount of fusaric acid ( $300 \mathrm{mg} /$ day for adults), administered orally, causes noradrenaline to be released and noradrenaline biosynthesis to be accelerated later. With larger doses $(600 \mathrm{mg} /$ day $)$, however, this trend was not conspicuous.

\section{Acknowledgement}

The author expresses his heart-felt thanks to Prof. Shoji Hayase for kindly guiding him in this investigation and for reading the manuscript; thanks are also due to Associate Prof. Senri Hirakawa for his constant guidance, kind advice and supervising. He also thanks Dr. Yoichi Seryu, 3rd Department of Internal Medicine, Kyoto University, for his kind guidance into the art of catecholamine measurement. Last but not least, I feel grateful to my colleagues Drs. T. Tokoro, T. Fukuta, $N$. Ohta, and K. Toyota for their cooperation.

\section{REFERENCES}

1. HIDAKA, H., NAGATSU, T., TAKEYA, K., TAKEUCHI, T., SUDA, H., KOJIRI; K., MATSUZAKI, M., \& UMEZAWA, H.: Fusaric acid, a hypo- 
tensive agent produced by fungi. J. Antibiotics 22: $228,1969$.

2. NAGATSU, T., HIDAKA, H., KAZUYA, H., TAKEYA, K., UMEZAWA, H., TAKEUCHI, T., \& SUDA, H.: Inhibition of dopamine beta-hydroxylase by fusaric acid (5-butylpicolinic acid) in vivo and in vitro. Biochem. Pharmacol. 19: 35, 19.70.

3. SUDA, H., TAKEUCHI, T., NAGATSU, T., MATSUZAKI, M., MATSUMOTO, I., \& UMEZAWA, H.: Inhibition of dopamine beta-hydroxylase by 5 -alkylpicolinic acid and their hypotensive effects. Chem. Pharm. Bull. 17: 2377, 1969.

4. HIDAKA, H.: Fusaric (5-butylpicolinic) acid, an inhibitor of dopamine beta-hydroxylase, affects serotonin and noradrenaline. Nature 231: 54, 1971.

5. TERASAWA, F. \& KAMEYAMA, M.: The clinical trial of a new hypotensive agent, "fusaric acid (5-butylpicolinic acid)": the preliminary report. Jap. Circul. J. 35: 339, 1971.

6. OATES, J. A., GILLESPIE, L., UDENFRIEND, S., \& SJOERDSMA, A.: Decarboxylase inhibition and blood pressure reduction by alpha-methyl-3,4-dihydroxy-dl-phenylalanine. Science 131: 1890 , 1960.

7. DAY, M. D. \& RAND, M. J.: A hypothesis for the mode of action of alpha-methyldopa in relieving hypertension. J. Pharmacol. 15: 221, 1963.

8. CARLSSON, A. \& LINDQVIST, M.: In-vivo decarboxylation of alpha-methyl dopa and alphamethyl metatyrosine. Acta Physiol. Scand. 54: 87, 1962.

9. EULER, U. S. v.,\& LISHAJKO, F.: The estimation of catecholamines in urine. Acta Physiol. Scand. 45: 122, 1959.

10. SANO, K., GAMOH, T., \& HASHIMOTO, Y.: Folia Endocr. Jap. 35: 86, 1960 (in Japanese).

11. NIKODIJEVIC, B., CREVELING, C. R., \& UDENFRIEND, S.: Inhibition of dopamine beta-oxidase in vivo by benzyl-exyamine and benzylhydrazine analogs. J. Pharmacol. 140: 224, 1963.
12. MUSACCHIO, J., KOPIN, I. J., \& SNYDER, S.: Effects of disulfiram on tissue norepinephrine content and subcellular distribution of dopamine, tyramine and their beta-metabolites. Life Science 3: $769,1964$.

13. THOENEN, H., HAEFELY, W., GEY, K. F., \& HUER LIMANN, A.: Diminished effects of sympathetic nerve stimulation in cats pretreated with disulfiram; liberation of dopamine as sympathetic transmitter. Life Science 4: 2033, 1966.

14. KOPIN, I. J. \& GORDON, E. K.: Metabolism of norepinephrine- $\mathrm{H}^{3}$ released by tyramine and reserpine. J. Pharmacol. Exp. Ther. 138: 351, 1962.

15. BURN, J. H. \& RAND, M. J.: The action of sympathomimetic amines in animals treated with reserpine. J. Physiol. 144: 314, 1958.

16. LOCKETT, M. F. \& EAKINS, K. E.: Chromatographic studies of intravenous injection of tyramine on the concentrations of adrenaline and noradrenaline in plasma. J. Pharm. Pharmacol. 12: 513, 1960.

17. BRIDGERS, W. F. \& KAUFMAN, S.: The enzymatic conversion of epinine to epinephrine. $J$. Biol. Chem. 237: 526, 1962.

18. OHI, Y.: Effects of hypothalamic on catecholamine contents and its related enzyme activities in sympathetic innervated organs of unanesthetized rabbits. Osaka Daigaku Igaku Zasshi 19: 217, 1967 (in Japanese).

19. IMAIZUMI, R. (ed.): Catecholamine. 1st Ed., Tokyo, Japan, Igaku Shoin Ltd., 1968, p.26. (in Japanese).

20. WURTMAN, R. J.: Catecholamines. New Eng. J. Med. 273: 746, 1965.

21. DEQUATTRO, V.: Evaluation of increased norepinephrine excretion in hypertension using LDopa- ${ }^{3}$ H. Circul. Res. 28: 84, 1971.

22. SERIU, Y.: High blood pressure and catecholamines. Saishin Igaku 22: 1108, 1967 (in Japanese). 